\title{
DETECTION AND COAT PROTEIN GENE CHARACTERIZATION OF AN ISOLATE OF Grapevine virus $B$ FROM CORKY BARK-AFFECTED GRAPEVINES IN SOUTHERN BRAZIL
}

\author{
OSMAR NICKEL ${ }^{1}$, THOR V. M. FAJARDO ${ }^{1}$, FRANCISCO J. L. ARAGÃO ${ }^{2}$, \\ CÉSAR M. CHAGAS ${ }^{3} \&$ GILMAR B. KUHN ${ }^{1}$
}

${ }^{1}$ Embrapa Uva e Vinho, Cx. Postal 130, CEP 95700-000, Bento Gonçalves, RS, e-mail: nickel@ cnpuv.embrapa.br; ${ }^{2}$ Embrapa Recursos Genéticos e Biotecnologia, Parque Estação Biológica, Av. W5 Norte, CEP 70770-900, Brasília, DF; ${ }^{3}$ Centro de Biotecnologia, Instituto Biológico, Cx. Postal 12.898, CEP 04014-970, São Paulo, SP

(Accepted for publication on 08/04/2002)

Corresponding author: Osmar Nickel

NICKEL, O., FAJARDO, T.V.M., ARAGÃO, F.J.L., CHAGAS, C.M. \& KUHN G.B. Detection and coat protein gene characterization of an isolate of Grapevine virus B from corky bark-affected grapevines in Southern Brazil. Fitopatologia Brasileira 27:279-284. 2002.

\begin{abstract}
An isolate of Grapevine virus $B(\mathrm{GVB})$, obtained by indexing Vitis labrusca and $V$. vinifera grapevines on the indicator LN33, was transmitted mechanically to several Nicotiana species. The virus was partially purified from $N$. cavicola and the coat protein estimated at $23 \mathrm{kDa}$ by SDS-PAGE. In negatively stained leaf extracts of experimentally inoculated $N$. cavicola and $N$. occidentalis, flexuous particles with cross banding were observed, predominantly measuring 750-770 x $12 \mathrm{~nm}$, with a modal length of $760 \mathrm{~nm}$. Decoration indicated a clear, positive reaction against AS-GVB. In DAS-ELISA, GVB was detected in N. cavicola and grapevine

extracts, and Western blots showed homologous and cross reaction of GVB and GVA antisera with GVB coat protein. Using specific primers for GVB, a fragment of $594 \mathrm{bp}$, comprising the coat protein gene coding for 197 amino acids, was amplified by RT-PCR with viral RNA extracted from GVB-infected $N$. occidentalis. The nucleotide and the deduced amino acid sequences of the coat protein gene showed high identities with Italian and Japanese isolates of GVB.

Additional keywords: GVB, Vitis spp., Vitivirus, electron microscopy, ELISA, Western blot, GVA.

\section{RESUMO \\ Deteç̧ão e caracterização do gene da proteína capsidial de um isolado de Grapevine virus $B$ de videiras do Sul do Brasil com intumescimento dos ramos}

Um isolado de Grapevine virus B (GVB), obtido por indexação de Vitis labrusca e V. vinifera na indicadora LN33, foi transmitido mecanicamente para várias espécies do gênero Nicotiana. O vírus foi parcialmente purificado de $N$. cavicola e a proteína capsídica foi estimada em $23 \mathrm{kDa}$ por SDS-PAGE. Ao microscópio eletrônico, observou-se, em extrato foliar de $N$. occidentalis e $N$. cavicola, partículas flexuosas com estriações transversais, predominantemente medindo 750-770 x $12 \mathrm{~nm}$, com comprimento modal de $760 \mathrm{~nm}$. A decoração das partículas indicou reação clara e positiva com anti-soro contra GVB. Em

DAS-ELISA, GVB foi detectado em extratos de Nicotiana spp. e de videira (Vitis spp.). Em Western blots foram observadas reações específicas e cruzadas, da proteína capsídica de GVB com os anti-soros contra GVB e GVA, respectivamente. A partir do RNA viral extraído de $N$. occidentalis, foi amplificado por RT-PCR um fragmento de 594 bp específico de GVB, que codificou 197 aminoácidos do gene da proteína capsídica. As sequiências de nucleotídeos e de aminoácidos deduzidos do gene da proteína capsidial apresentaram alta identidade com isolados italianos e japoneses de GVB.
\end{abstract}

\section{INTRODUCTION}

Corky bark, a component of the grapevine (Vitis spp.) rugose wood complex, is caused by Grapevine virus $B$ (GVB), genus Vitivirus (Regenmortel et al., 2000), which is widespread worldwide in grape growing regions (Martelli, 1993). The virus has filamentous particles of ca. $800 \mathrm{~nm}$ length, and a single type of coat protein (CP) subunit with a molecular mass of $21.6-23 \mathrm{kDa}$, according to whether estimates are made from the amino acid sequence of the CP cistron (Minafra et al., 1994) or from the electrophoretic mobility of purified virus preparations (Boscia et al., 1993).
The genome is a positive, single-stranded RNA of about 7,600 nucleotides in size (Boscia et al., 1993). The viral genome has been sequenced (Minafra et al., 1994; Saldarelli et al. 1996). Although GVB has been recently reported in the Brazilian States of São Paulo (Kuniyuki et al., 2000) and Rio Grande do Sul (Nickel et al., 2000), the corky bark-affected grapevines have been indexed earlier (Kuniyuki \& Costa, 1987; Kuhn, 1992). With an incidence of up to $60 \%$ in some vineyards in southern Brazil, it is highly relevant economically. Corky bark causes decreased production, incomplete ripening of grapes and progressive decline and death of Vitis labrusca L. and V. vinifera grape cultivars 
(Kuhn, 1992). Cultivars and rootstocks differ in their susceptibility to the disease. Some are symptomless carriers or exhibit only mild symptoms, while others suffer rapid decline. Typically swelling and longitudinal bark cracks in young branches and the early drying of branches occur in $V$. labrusca, while the reaction of $V$. vinifera cultivars is restricted to swelling at the graft region and /or precocious reddening of leaves. There is evidence of the natural spread of this disease worldwide, including the Serra Gaúcha, Rio Grande do Sul. There is experimental proof of controled transmition of GVB by several species of the pseudococcid mealybug genera Pseudococcus and Planococcus (Engelbrecht \& Kasdorf, 1990; Boscia et al., 1993; Garau et al., 1995; Golino et al., 1995), which is consistent with the distribution pattern of the disease in vineyards indicating the involvement of a vector. Since symptoms are not always expressed in affected seedlings, precise and efficient diagnostic methods are relevant.

Here we report on the diagnosis and the characterization of the coat protein gene of a Brazilian isolate of GVB (named GVB BR1), as well as the involvement of this virus in corky bark grapevine disease in Southern Brazil and the biological reaction it induces in infected herbaceous indicator plants.

\section{MATERIAL AND METHODS}

\section{Virus sources and mechanical inoculation of herbaceous hosts}

The isolate GVB BR1 was obtained by indexing $V$. labrusca cvs. Isabel and Niagara, and $V$. vinifera grapevines cvs. Gewürztraminer and Cabernet Sauvignon on the indicator LN33 (Couderc 1613 x Thompson Seedless) during a survey carried out in the counties of Bento Gonçalves and Farroupilha, Brazil (Kuhn, 1992). The virus was recovered from corky bark-affected LN33 by grinding mature leaves (or main veins and petioles) in the presence of $50 \mathrm{mM}$ potassium phosphate buffer $\mathrm{pH} 7.5$, containing $2.5 \%$ nicotine and mechanically inoculating it on to carborundum-dusted leaves of Chenopodium amaranticolor Coste et Reyn, $C$. quinoa Willd., Nicotiana occidentalis Wheeler, $N$. occidentalis sp. obliqua, N. occidentalis sp. obliqua $\mathrm{P} 1, N$. occidentalis $37 \mathrm{~B}, N$. benthamiana Domin., and $N$. cavicola. Latent infections were ascertained by back inoculating on $N$. occidentalis and by electron microscopy.

\section{Virus purification, serology and electron microscopy}

GVB was partially purified from $N$. cavicola or $N$. occidentalis adopting the procedure of Boscia et al. (1993) with minor modifications. Briefly, systemically infected leaves were powdered in the presence of liquid nitrogen, extracted in buffer, clarified, concentrated by cycles of differential centrifugation and submitted to one cycle of ultracentrifugation in a $\mathrm{CsSO}_{4}$ gradient. The virus bands were extracted with hypodermic needles, dialysed, given a 12.000 g centrifugation and stored at $-20{ }^{\circ} \mathrm{C}$.
ELISA and Western blots were carried out using policlonal GVB antiserum against an Italian isolate of GVB (kindly supplied by G.P. Martelli, Bari, Italy), a policlonal Grapevine virus $A$ (GVA) antiserum (kindly supplied by Istituto de Fitovirologia Applicata, Turin, Italy) and commercial policlonal antisera against GVB and GVA (Sanofi, France or Agritest, Italy) with extracts of GVBaffected Nicotiana spp. cultivated in a glasshouse and of corky bark-infected grapes (veins and petioles of mature leaves). Samples for ELISA (Clark \& Adams, 1977) were diluted 1:5 (w/v) and analysed according to standard methods. Aliquots of the virus suspension were denatured with an equal volume of SDS-PAGE sample buffer (Sambrook et al., 1989) and electrophoresed in a discontinuous polyacrylamide gel system at $120 \mathrm{~V}$ for $2 \mathrm{~h}$ in running buffer (Laemmli, 1970) in a vertical mini-PAGE unit. The molecular weight of protein subunits was determined by comparison with molecular weight standards. Gels were stained with silver nitrate (Blum et al., 1987). Electrotransfer of proteins to nitrocellulose membranes for Western blots was done from unstained gels at $100 \mathrm{~V}$ for $1 \mathrm{~h}$ in transfer buffer (Towbin et al., 1979). Besides partially purified GVB suspension, crude extracts of petioles and veins of GVB infected plants were used for Western blot analysis.

For virus particle observations, foliar extracts of infected $N$. cavicola and $N$. occidentalis were negatively stained with $2 \%$ uranyl acetate, mounted on carbon-stabilized collodion-coated grids and examined in a Philips EM 208 electron microscope. One hundred-seven particles were measured and grouped at $10 \mathrm{~nm}$ class intervals. Decoration tests were performed according to Milne \& Lesemann (1984), using the antisera against GVB and GVA mentioned above.

\section{Synthesis of cDNA, RT-PCR amplification, cloning and sequencing}

Viral RNA was extracted by adsorbing total nucleic acids on silica particles as described previously (Nickel et al., 1999). Preparation of silicon dioxide was done according to Boom et al. (1990). Complementary GVB7038 (5' ACTCGTCAGACAACTCTATATC 3') and homologous primers GVB6445 (5' ATGGAAAATATATCCCGGATGG 3') were synthesized according to published sequences (Saldarelli et al., 1996; GenBank data, access code X75448). Alternatively, the same reaction was carried out with primers GVB H28 (5'GTGCTAAGAACGTCTTCACAGC3') and C410 (5'ATCAGCAAACACGCTTGAACCG3') (Minafra \& Hadidi, 1994). For reverse transcription $5 \mu \mathrm{l}$ of viral RNA template were mixed with $0.5 \mu \mathrm{l}$ complementary primer GVB $7038(1 \mu \mathrm{g} / \mu \mathrm{l}), 4.5 \mu \mathrm{l}$ deionized water, and incubated $2 \mathrm{~min}$ at $90{ }^{\circ} \mathrm{C}$. After primer annealing at room temperature for 3 min, $15 \mu \mathrm{l}$ of reaction mixture [containing $5 \mu \mathrm{l}$ M-MLV 5x buffer, $0.7 \mu$ l RNAse inhibitor (40 U/ $\mu \mathrm{l}), 1 \mu \mathrm{l} 10 \mathrm{mM}$ dNTP (2.5 mM each), $1 \mu \mathrm{l} \mathrm{M-MLV} \mathrm{reverse} \mathrm{transcriptase} \mathrm{(200} \mathrm{U/}$ $\mu 1)$ and $7.3 \mu \mathrm{l}$ water] were added and the mixture was incubated at $37{ }^{\circ} \mathrm{C}$ for $1 \mathrm{~h}$. Aliquots of $40 \mu \mathrm{l}$ of the amplification mixture [5.0 $\mu 1$ 10x Taq DNA polymerase buffer, 
Detection and coat protein gene characterization of an isolate of...

$5.0 \mu \mathrm{l} 10 \mu \mathrm{M}$ dNTPs $(2.5 \mu \mathrm{M}$ each), $1 \mu \mathrm{l}$ of each primer, 0.5 $\mu \mathrm{l}$ (0.5 unit) of $\mathrm{Taq}$ DNA polymerase and $27.5 \mu \mathrm{l}$ water] were mixed with a $10 \mu \mathrm{l}$ aliquot of the cDNA reaction. The PCR amplification profile was 30 cycles of $30 \mathrm{sec}$ at $94^{\circ} \mathrm{C}, 30 \mathrm{sec}$ at $62{ }^{\circ} \mathrm{C}$, and $45 \mathrm{sec}$ at $72{ }^{\circ} \mathrm{C}$ (denaturing, annealing and extension, respectively) and a final elongation step of $5 \mathrm{~min}$ at $72{ }^{\circ} \mathrm{C}$. An aliquot of the PCR amplification reaction was run in a $1.5 \%$ agarose gel for $2 \mathrm{~h}$ at $70 \mathrm{~V}$. Molecular weight marker Lambda DNA cut with Pst $I$ was used to determine the size of amplification products, which were stained with ethidium bromide and visualized over UV light. Viral bands were immediately cut out of the gel and DNA was eluted for cloning procedures.

The amplified fragment with $594 \mathrm{bp}$ was cloned into a pGEM-T Easy vector (Promega) and used to transform competent JM 109 Escherichia coli cells according to the manufaturer's instructions. Ampicillinresistant transformants were selected and recombinant plasmids were isolated from overnight cultures by cell lysis (Sambrook et al., 1989). Purified plasmid DNA was sequenced on an automatic sequencer. Sequence data were analysed using the Blast resources through the National Center for Biotechnlogy Information (NCBI) (http:// www.ncbi.nlm.nih.gov/). Search and alignment of the sequenced clone were done within the GenBank database.

\section{RESULTS}

\section{Virus sources and mechanical inoculation of herbaceous} hosts

GVB isolate BR1 was successfully transmitted mechanically from LN33 to all Nicotiana species mentioned, except $N$. benthamiana, C. quinoa and C. amaranticolor, which were not infected. Symptoms appeared at seven to nine days post-inoculation.

Nicotiana occidentalis 37B and N. occidentalis spp. obliqua $\mathrm{P} 1$ are severely affected by the virus, initially showing necrotic spotting and necrotic areas on the stems, and later a systemic necrosis, leaf deformation and size reduction, dwarfing and a rosette-like growth. In the late stages of infection, leaves and stems turn lilac. Sometimes infection was lethal to these species.

Nicotiana occidentalis, $N$. occidentalis spp. obliqua and $N$. cavicola initially show chlorotic spotting and vein clearing that turn necrotic, forming a necrotic net over the leaf surface. Leaves with symptoms are wrinkled, and their size is gradually reduced. In late infection stages plant habitus is rosette-like. Infection is heavy but not lethal.

\section{Partial purification, serology and electron microscopy/ ISEM}

Coat protein subunits were estimated at $23 \mathrm{kDa}$ by SDS-PAGE in partially purified virus suspensions and by Western blot in GVB-infected grapevine leaf extracts (data not shown). Western blots revealed homologous and heterologous reactions (data not shown) of GVB BR1 coat protein respectively with a GVB antiserum (Agritest, Italy) and GVA antiserum (Turin, Italy). In ELISA, reactions were homologous only (Table 1).

In negatively stained leaf extracts of experimentally inoculated $N$. cavicola and $N$. occidentalis, flexuous particles, with the cross banding typical of Vitivirus were observed, predominantly measuring $750-770 \times 12 \mathrm{~nm}$ with modal length of $760 \mathrm{~nm}$ (Figure 1A). In ISEM GVB BR1 particles were heavily decorated, indicating a strong positive reaction against GVB antiserum (Figure 1B). Decoration with GVA antiserum was negative.

\section{PCR, cloning, sequence determination and homology analysis}

An expected 594 bp DNA fragment comprising the complete coat protein gene of GVB BR1 was amplified (Figure 2 ). The open reading frame (ORF) representing the GVB coat protein gene contained 591 nucleotides, coding for a protein of 197 amino acids with a predicted $\mathrm{M}_{\mathrm{r}}$ of about $23 \mathrm{kDa}$. The nucleotide and the deduced amino acid sequences of GVB BR1 coat protein gene (Figure 3) are accessible in the GenBank database under number AF438410.

The nucleotide and deduced amino acid sequences of the coat protein gene showed high identities with other two isolates of GVB: $81.1 \%$ and $97.4 \%$ with an Italian isolate (X75448), and $81.4 \%$ and $94.9 \%$ with a Japanese isolate (AB039842), respectively (Table 2).

Comparison of the amino acid sequence of GVB BR1 coat protein gene with related virus species and viral proteins revealed extensive homologies with Vitivirus such as Heracleum latent virus (HLV), Grapevine virus D (GVD) and GVA, and lower homologies with virus from the genera Trichovirus and Capillovirus (Table 3).

\section{DISCUSSION}

Mechanical transmission, directly from field (or glasshouse-) grown vines, was successful though not easily performed. As reported for other phloem-limited grapevine viruses, transmission of GVB is more likely to succeed when in vitro-grown explants are used as the inoculum source

TABLE 1 - ELISA of Nicotiana spp. and grapevine (Vitis spp.) cv. LN33 grown under greenhouse conditions performed using a polyclonal antiserum against Grapevine virus B (GVB). ELISA values at $405 \mathrm{~nm}$ were an average of two samples

\begin{tabular}{lc}
\hline \hline SAMPLE & ELISA VALUE \\
\hline Grapevine cv. LN33 healthy & 0.243 \\
Grapevine cv. LN33 infected & 2.224 \\
N. cavicola healthy & 0.242 \\
N. cavicola infected & 0.554 \\
Negative control of ELISA test & 0.234 \\
GVB positive control of ELISA test & 1.764 \\
\hline
\end{tabular}


O. Nickel et al.

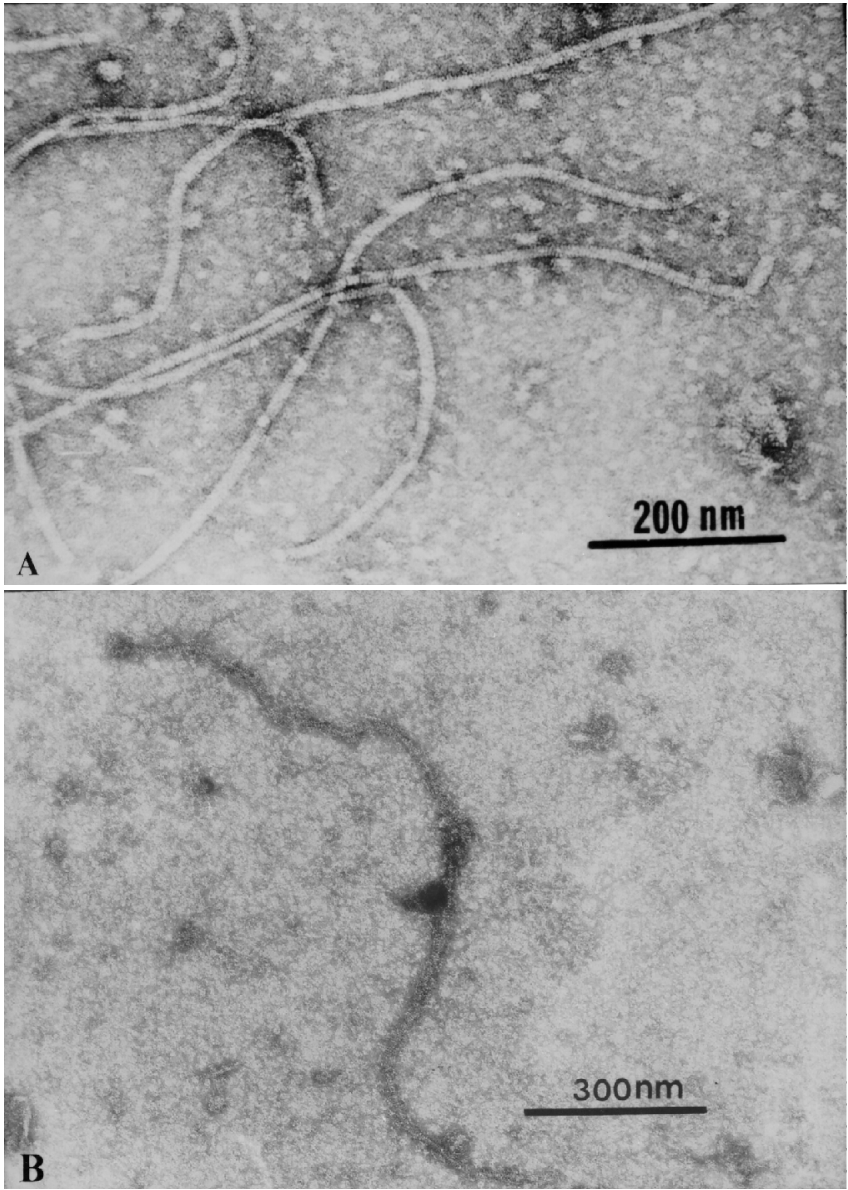

FIG. 1 - A. Electron micrographs of Grapevine virus $B$ (GVB) BR1 particles from a leaf extract of Nicotiana occidentalis; B. Two GVB BR1 particles, joined by their extremities, from a leaf extract of $N$. cavicola decorated by an antiserum against GVB, both negatively stained in $2 \%$ uranile acetate.

(Bonavia et al., 1996). Our attempts were unsuccesful to in vitro grow GVB-affected LN33 in Galzy medium (Galzy, 1964), in which we do routine vegetative propagation of grapevines. Growth of these cultures was extremely poor; most explants did not produce any shoots. Among species that were not infected, $N$. benthamiana is known as a difficult host (with Italian isolates), that could eventually be infected using viral RNA (A. Minafra, Italy, personnal communication) although it is easily infected by South African isolates (Goszczynski et al., 1996). The existence of biologically different strains, based on differential reaction of $N$. occidentalis, has been reported (Boscia et al., 1993). By the same logic, non-infection of $N$. benthamiana by GVB BR1 characterizes it as a biologically different strain. It can not be excluded that the inoculum used here may contain more than one strain. This view is consistent with the different reactions produced occasionally on the same indicator by the same inoculum (vein chlorosis or necrosis of N. cavicola, not shown). It should be stressed that GVB BR1

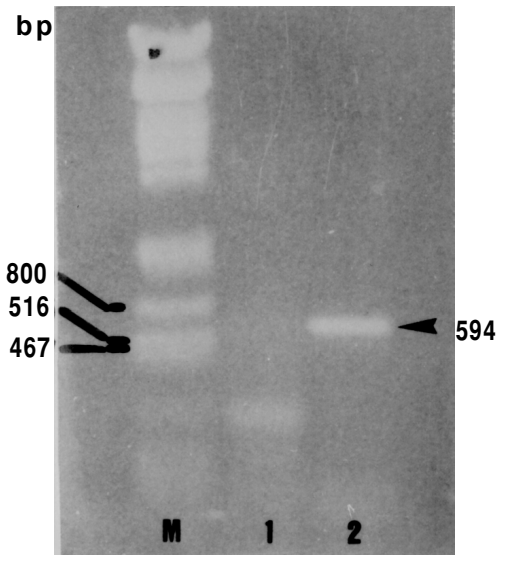

FIG. 2 - Electrophoretic analysis of PCR amplification products from total RNA of Nicotiana cavicola inoculated with Grapevine virus B (GVB) BR1, agarose $1.2 \%$. Lanes (1) negative reaction with GVA primers (Minafra \& Hadidi, 1994), (2) amplified fragment of GVB BR1 of 594 bp, (M) molecular weight marker, PstI-cut Lambda DNA.

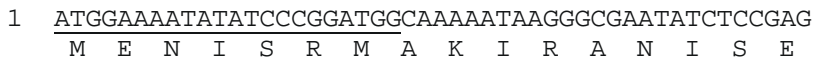

49 CTCCTGTGCGCGGGAGTCACATTTGTAACTGACGCCCGTGAAACTGGG $\begin{array}{llllllllllllllll}\mathrm{L} & \mathrm{L} & \mathrm{C} & \mathrm{A} & \mathrm{G} & \mathrm{V} & \mathrm{T} & \mathrm{F} & \mathrm{V} & \mathrm{T} & \mathrm{D} & \mathrm{A} & \mathrm{R} & \mathrm{E} & \mathrm{T} & \mathrm{G}\end{array}$

97 TTtGATCGTCCCATGTACTTCAGGACCCTATTCGGGTACATTGCATTA $\begin{array}{llllllllllllllll}F & D & R & P & M & Y & F & R & T & L & F & G & Y & I & A & L\end{array}$

145 ACTGGGACATCAGCAAAAGCACAGCACTACGAGAATGTAGATATTATA

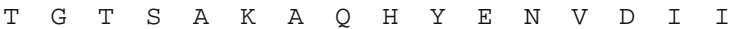

193 GGTGATAAAGTAGGAGCAGAGGGTCTAGATAGTAGGGGAACTGTCAAT

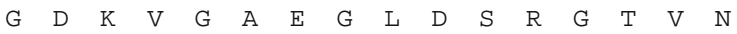

241 ATCTCGGAACAGGTGAAGAAGATGATGGGTTACTCTCGAGCAGTACCA $\begin{array}{llllllllllllllllllllll}I & S & E & Q & V & K & K & M & M & G & Y & S & R & A & V & P\end{array}$

289 TCTGGGGTGTGTAAGGGCCTTACTCTGAGGCAAATGTGTGAACCTTTC $\begin{array}{llllllllllllllll}S & G & V & C & K & G & L & T & L & R & Q & M & C & E & P & F\end{array}$

337 GCAGAGGAAGCTAGGGACTGCTTGACTATCCTGGCAACCCTGAGGGTA $\begin{array}{llllllllllllllll}A & E & E & A & R & D & C & L & T & I & L & A & T & L & R & V\end{array}$

385 TACAGCAGGCTCGCACTCAAGATGGCCAAACTGGGCCAAAAAGAACCC $\begin{array}{llllllllllllllll}Y & S & R & L & A & L & K & M & A & K & L & G & Q & K & E & P\end{array}$

433 CAAGTTATGTTCGATTTTAACTCTGGTCTTAACCTGCTCGCTCTATCC

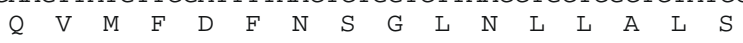

481 GCTACCGAGGCATCTGCAATACAATCTCTGAACTCAAGGCTCTTTCGA $\begin{array}{llllllllllllllll}A & \mathrm{~T} & \mathrm{E} & \mathrm{A} & \mathrm{S} & \mathrm{A} & \mathrm{I} & \mathrm{Q} & \mathrm{S} & \mathrm{L} & \mathrm{N} & \mathrm{S} & \mathrm{R} & \mathrm{L} & \mathrm{F} & \mathrm{R}\end{array}$

529 ACTGAGGGTGCAAAGAACGTATTCACAGCACAAGCCAGCGTGGGTGAG $\begin{array}{llllllllllllllll}T & E & G & A & K & N & V & F & T & A & Q & A & S & V & G & E\end{array}$

$577 \frac{\text { CAGTCTGTCGAGATATAG }}{\mathrm{Q} \text { S V E I * }} 594$

FIG. 3 - Nucleotide sequence of the coat protein gene of Grapevine virus $B$ (GVB) BR1. The deduced amino acid sequence of coat protein gene is shown below the nucleotide sequence. Asterisk indicates the coat protein termination codon; GVB 6445 and GVB 7038 are the 5' forward and the 3' reverse primers, respectively (underlined). This sequence is accessible at GenBank under number AF438410. 
Detection and coat protein gene characterization of an isolate of...

TABLE 2 - Pairwise percent identities among coat protein amino acid sequences (above diagonal) and coat protein nucleotide sequences (below diagonal) of Grapevine virus B Brazilian BR1 isolate (GenBank access AF438410) and other isolates

\begin{tabular}{|c|c|c|c|c|}
\hline & $\begin{array}{c}\text { GVB BR1 } \\
594 \text { bp/197 aa }\end{array}$ & $\begin{array}{l}G V B^{(1)} \\
X 75448 \\
\end{array}$ & $\begin{array}{c}G V B^{(2)} \\
\text { AB039842 }\end{array}$ & $\begin{array}{c}\mathrm{GVB}^{(3)} \\
2022155 E\end{array}$ \\
\hline $\begin{array}{l}\text { GVB BR1 } \\
594 \text { bp/197 aa }\end{array}$ & - & 97.4 & 94.9 & $96.8^{(*)}$ \\
\hline $\begin{array}{l}\mathrm{GVB}^{(1)} \\
\mathrm{X} 75448\end{array}$ & 81.1 & - & 94.9 & $99.4^{(*)}$ \\
\hline $\begin{array}{l}G V B^{(2)} \\
A B 039842\end{array}$ & 81.4 & 81.9 & - & $93.7^{(*)}$ \\
\hline $\begin{array}{l}\text { GVB }^{(3)} \\
2022155 E\end{array}$ & n.d. & n.d. & n.d. & - \\
\hline
\end{tabular}

n.d. - not determinated

(*) - To $2022155 \mathrm{E}$ GVB access only 191 amino acids sequence is available. Access: GVB BR1: Brazilian isolate of Grapevine virus B (GVB) (GenBank access AF438410), (1) Saldarelli et al. (1996), (2) Coat protein gene of Grapevine virus B (GVB) isolated in Japan (In press, 2000), (3) Minafra et al. (1994). GenBank database access code closed to virus name.

inoculum often induced a systemic necrotic reaction on $N$. occidentalis and occasionally a lethal reaction on $N$. occidentalis spp. obliqua $\mathrm{P} 1$. The virus could be detected in several Vitis spp. cultivars. As more sensitive diagnostic methods are used, besides making diagnosis of nonsymptomatic infections in nuclear mother stock and in nurseries more efficient and faster, the already high incidence of GVB (Kuhn, 1992) may turn out to be higher.

Usually commercial GVA antisera did not cross-react in ELISA with GVB BR1 or other GVB-positive tissues tested by ELISA. On the other hand, GVB BR1 reacted positively to the GVA antisera used in Western blots, which confirmed a previous report, demonstrating that both viruses share antigenic determinants (Goszczynski et al., 1996). It was shown that the reaction of antisera against GVB and GVA is virus-specific in ELISA and IEM, indicating that the antigenic determinants responsible for cross reactions in Western blots are mainly cryptotopes (Goszczynski et al., 1996), which are not accessible for antibodies when non-denatured samples are used in ELISA and electron microscopy. The intensity of the heterologous reaction observed in this work (data not shown) is surprizing, despite a distant serological relationship due to a few common internal antigenic determinants (Regenmortel et al., 2000).

The particle modal length of $760 \mathrm{~nm}$ of GVB BR1 fits the size range of the viruses for the genus Vitivirus (725-825 $\mathrm{nm}$ ) (Regenmortel et al., 2000) and agrees quite closely with values of American $(800 \mathrm{~nm})$ and Canadian $(775 \mathrm{~nm}) \mathrm{GVB}$ isolates (Boscia et al., 1993).

Alignment of the coat protein gene sequences of GVB BR1 with sequences of GVA, GVD and HLV, the other members of the newly created genus Vitivirus, showed extensive homologies at the aminoacid level, confirming a similar report by Goszczynski et al. (1996) based on Western blot results and Regenmortel et al. (2000).

The unequivocal identification of GVB in corky barkaffected LN33 in connection with the non-amplification of GVA by RT-PCR (Figure 2) and the non-decoration of particles in IEM with GVA-AS, excludes the hypothesis of GVA presence in these samples and underlines the association of GVB with corky bark etiology.

The obtained sequence data show a small variability

TABLE 3 - Comparison (in percentage of identity) between deduced amino acid of coat protein genes of Grapevine virus $B$ (GVB) BR1 (AF438410) and viruses from related genera

\begin{tabular}{|c|c|c|c|}
\hline VIRUS & GENUS & GENBANK ACCESS & HOMOLOGIES \\
\hline 1. Heracleum latent virus (HLV) & Vitivirus & X79270 & $66.4(131 / 197)$ \\
\hline 2. Grapevine virus $D$ (GVD) & Vitivirus & Y07764 & $63.9(103 / 161)$ \\
\hline 3. Grapevine virus $A$ (GVA) & Vitivirus & AF007415 & $57.0(113 / 198)$ \\
\hline 4. Grapevine virus $A$ (GVA) & Vitivirus & AB039841 & $57.0(113 / 198)$ \\
\hline 5. Grapevine virus $A$ (GVA) & Vitivirus & X75433 & $56.0(111 / 198)$ \\
\hline 6. Citrus tatter leaf virus (CTLV) & Capillovirus & AF233298 & $36.4(39 / 107)$ \\
\hline 7. Apple chlorotic leaf spot virus (ACLSV) & Trichovirus & X99752 & $33.7(54 / 160)$ \\
\hline 8. Cherry virus $A$ (ChVA) & Capillovirus & X82547 & $33.5(54 / 161)$ \\
\hline 9. Cherry mottle leaf virus (ChMLV) & Trichovirus & AF 170028 & $33.3(52 / 156)$ \\
\hline 10. Apple chlorotic leaf spot virus (ACLSV) & Trichovirus & $\mathrm{C} 45353$ & $31.8(51 / 160)$ \\
\hline 11. Apple chlorotic leaf spot virus (ACLSV) & Trichovirus & M58152 & $31.8(51 / 160)$ \\
\hline 12. Apple chlorotic leaf spot virus (ACLSV) & Trichovirus & AF251275 & $31.8(51 / 160)$ \\
\hline 13. Apple chlorotic leaf spot virus (ACLSV) & Trichovirus & D14996 & $31.2(50 / 160)$ \\
\hline 14. Apple chlorotic leaf spot virus (ACLSV) & Trichovirus & $\mathrm{AJ} 243438$ & $30.6(50 / 163)$ \\
\hline 15. Apple stem grooving virus (ASGV) & Capillovirus & AB004063 & $30.5(52 / 170)$ \\
\hline 16. Citrus tatter leaf virus (CTLV) & Capillovirus & $2121406 \mathrm{~A}$ & $30.5(52 / 170)$ \\
\hline 17. Citrus tatter leaf virus (CTLV) & Capillovirus & D14455 & $30.5(52 / 170)$ \\
\hline 18. Citrus tatter leaf virus (CTLV) & Capillovirus & D16368 & $30.5(52 / 170)$ \\
\hline 19. Apple stem grooving virus (ASGV) & Capillovirus & D14995 & $30.0(51 / 170)$ \\
\hline
\end{tabular}

${ }^{(*)}$ Identical amino acids/aligned amino acids 
of coat protein genes among three GVB isolates from distinct geographical regions. However GVB BR1 is less close to GVA (56-57\% homology) than Italian isolates of GVB (59\%) (Saldarelli et al., 1996). Our data, agreeing with Minafra et al. (1994), reveal some homology of GVB with coat protein genes of Apple chlorotic leaf spot virus (ACLSV) genus Trichoviruses and Apple stem grooving virus (ASGV) genus Capillovirus (Table 3).

\section{LITERATURE CITED}

BONAVIA, M., DIGIARO, M., BOSCIA, D., BOARI, A., BOTTALICO, G., SAVINO, V. \& MARTELLI, G.P. Studies on "corky rugose wood" of grapevine and on the diagnosis of grapevine virus B. Vitis 35:53-58. 1996.

BLUM, H., BEIER, H. \& GROSS, H.J. Improved silver staining of plant proteins, RNA and DNA in polyacrylamide gels. Electrophoresis 8:93-99. 1987.

BOOM, R.C.J.A., SOL, M.M.M., SALIMANS, C.L., JANSEN, P.M.E., WERTHEIM-VAN DILLEN \& VAN DER NOORDAA, J. Rapid and simple method for purification of nucleic acids. Journal of Clinical Microbiology 28:495-503. 1990.

BOSCIA, D., SAVINO, V., MINAFRA, A., NAMBA. S., ELICIO, V., CASTELLANO, M.A., GONSALVES, D. \& MARTELLI, G.P. Properties of a filamentous virus isolated from grapevines affected by corky bark. Archives of Virology 130:109-120. 1993.

CLARK, M.F. \& ADAMS, A.N. Characteristics of the microplate method of enzyme linked immunosorbent assay for the detection of plant viruses. Journal of General Virology 34:475483. 1977.

ENGELBRECHT, D.J. \& KASDORF, G.G.F. Field spread of corky bark, fleck, leafroll and Shiraz decline diseases and associated viruses in South African grapevines. Phytophylactica 22:347354. 1990.

GALZY, R. Technique de thermotherapie des viroses de la vigne. Annales der Epiphyties 15:245-256. 1964.

GARAU, R., PROTA, V.A., BOSCIA, D., FIORI, M. \& PROTA, U. Pseudococcus affinis Mask., new vector of grapevine trichoviruses A and B. Vitis 34:67-68. 1995.

GOLINO, D.A., SIM, S.T. \& ROWHANI, A. Transmission studies of grapevine leafroll associated virus and grapevine corky bark associated virus by the obscure mealbug. American Journal of Enology and Viticulture 46:408. 1995 (Abstract).

GOSZCZYNSKI, D.E., KASDORF, G.G.F. \& PIETERSEN, G. Western blots reveal that grapevine viruses $\mathrm{A}$ and $\mathrm{B}$ are serologically related. Journal of Phytopathology 144:581-583. 1996.
KUHN, G.B. Intumescimento dos ramos da videira ("corky bark"), doença constatada no Rio Grande do Sul. Fitopatologia Brasileira 17:399-406. 1992.

KUNIYUKI, H. \& COSTA, A.S. Incidência de vírus da videira em São Paulo. Fitopatologia Brasileira 12:240-245. 1987.

KUNIYUKI, H., REZENDE, J.A.M., KITAJIMA, E.W., YUKI, V.A. \& BETTI, J.A. Detecção do Grapevine virus $B$ em videiras com a doença fendilhamento cortical. Fitopatologia Brasileira 25:443. 2000 (Resumo).

LAEMMLI, U.K. Cleavage of structure proteins during the assembly of the head of bacteriophago T4. Nature 227:680-685. 1970.

MARTELLI, G.P. Graft-transmissible diseases of grapevines: handbook for detection and diagnosis. Rome. FAO. 1993.

MILNE, R.G. \& LESEMANN, D.E. Immunosorbent electron microscopy in plant virus studies. In:Maramorosch, K. \& Koprowski, H. (Ed.). Methods in Virology. v. VIII. New York and London. Academic Press. 1984. pp. 85-101.

MINAFRA, A. \& HADIDI, A. Sensitive detection of grapevine virus A, B, or leafroll-associated III from viruliferous mealybugs and infected tissue by cDNA amplification. Journal of Virological Methods 47:175-188. 1994.

MINAFRA, A., SALDARELLI, P., GRIECO, F. \& MARTELLI, G.P. Nucleotide sequence of the 3 ' terminal region of the RNA of two filamentous grapevine viruses. Archives of Virology 137:249-261. 1994.

NICKEL, O., JELKMANN, W. \& KUHN, G. Occurrence of Apple stem grooving capillovirus in Santa Catarina, Brazil, detected by RT-PCR. Fitopatologia Brasileira 24:444-446. 1999.

NICKEL, O., CHAGAS, C.M., FAJARDO, T.V.M. \& KUHN, G.B. Detection and partial characterization of an isolate of Grapevine virus $B$ in corky bark-affected grapevines. Fitopatologia Brasileira 25:445. 2000 (Resumo).

REGENMORTEL, M.H.V., FAUQUET, C.M., BISHOP, D.H.L., CARSTENS, E.B., ESTES, M.K., LEMON, S.M. MANILOFF, J., MAYO, M.A., McGEOCH, D.J., PRINGLE, C.R. \& WICKNER. R.B. (Eds.). Genus Vitivirus. Virus Taxonomy Classification and Nomenclature of Viruses. San Diego. Academic Press. 2000. pp. 960-964.

SALDARELli, P., MINAFRA, A. \& MARTELLI, G.P. The nucleotide sequence and genomic organization of grapevine virus B. Journal of General Virology 77:2645-2652. 1996.

SAMBROOK, J., FRITSCH, E.F. \& MANIATIS, T. Molecular Cloning - A Laboratory Manual. Second edition. New York. Cold Spring Harbor Laboratory Press. 1989.

TOWBIN, H., STAEHELIN, T. \& GORDON, J. Electrophoretic transfer of proteins from polyacrylamide gels to nitrocellulose sheets:procedure and some applications. Proceedings of the National Academy of Sciences of the USA 76:4350-4354. 1979. 